\title{
ХАРАКТЕР АКТИВНОСТІ АЛЬФА-АМІЛАЗИ ПЕРИФЕРИЧНОЇ КРОВІ У ХВОРИХ НА ГОСТРИЙ ПАНКРЕАТИТ
}

Вищий державний навчальний заклад України "Буковинський державний медичний університет", м. Чернівці

\begin{abstract}
Резюме. Гострий панкреатит характеризується значними порушеннями різних ланок гомеостазу. $\alpha$ амілаза $є$ одним 3 важливих маркерів запалення та деструкції тканини підшлункової залози, однак дані про динаміку цього показника $\epsilon$ суперечливими. Метою дослідження стало визначення динаміки активності $\alpha$ амілази периферичної крові при гострому панкреатиті. Дослідження включає результати динамічного обстеження 34 хворих на різні форми гострого панкреатиту. Серед них 9 (26,47\%) мали набрякову форму, 25 $(73,53 \%)$ - панкреанекроз. Середній вік пацієнтів складав $(48,11 \pm 5,99)$ років. Чоловіки переважали - 22 $(64,71 \%)$. Етіологія гострого панкреатиту в 11 $(32,35 \%)$ хворих - біліарного генезу, у $9(26,47 \%)-$
\end{abstract}

Вступ. Зростання кількості хворих на гострий панкреатит (ГП), висока частота виникнення ускладнень $з$ частими несприятливими наслідками визначає актуальність цієї проблеми $[6,7]$. Згідно зі статистичними даними, щорічна захворюваність на ГП досягає 200-800 випадків на 1 млн населення. Станом на початок XXI сторіччя в Україні захворюваність на ГП становить від 4,6 \% до 5,3 \% на 10 тис. населення, що приблизно відповідає 24000-25000 хворих на рік, з них у 4000-5000 встановлювався діагноз гострого некротичного панкреатиту (ГНП). У значної частини хворих, як правило, із субтотальними і тотальними формами панкреонекрозу вже в перші 72 год від початку захворювання розвивається синдром поліорганної дисфункції, що є основною причиною смерті близько $30 \%$ осіб у ці терміни захворювання $[2,3]$.

Дослідження щодо вивчення окремих аспектів патогенезу гострого некротичного панкреатиту (ГНП) проводяться в напрямку визначення ролі оксидантно-антиоксидантних порушень, змін системи гемостазу, гуморальних та гормональних порушень у розвитку системних уражень. Однак попри численні дослідження українських та зарубіжних учених, на сучасному етапі відсутня єдина думка щодо характеру змін гомеостазу при ГП $[4,5]$. $\alpha$-амілаза крові вважається одним iз основних маркерів деструкції панкреатичної залози, однак дані про динаміку іiі змін є суперечливими - від констатації багатократного іiї збільшення до мінімальних значень.

Мета дослідження. Встановити характер динаміки змін $\alpha$-амілази периферичної крові, як основного маркера деструкції тканини підшлункової залози, що виникає при гострому панкреатиті.

Матеріал і методи. Роботу виконано 3 дотриманням основних положень Конвенції Ради Європи про права людини та біомедицину та від(C) В.К. Гродецький, 2016 28 алкогольного, у 14 (41,18 \%) - аліментарного. Встановлено, що найвищі показники $\alpha$-амілази спостерігались у хворих на панкреонекроз. Однак значна варіабельність цього показника та відсутність прямої залежності між рівнем $\alpha$-амілази та тяжкістю перебігу панкреатиту не дозволяють рекомендувати цей параметр як прогностичний критерій. Характер змін активності амілази крові при гострому некротичному панкреатиті засвідчує розвиток цитолітичного синдрому, який, тим не менш, не має чіткого вірогідного взаємозв'язку з тяжкістю перебігу гострого панкреатиту.

Ключові слова: панкреатит, $\alpha$-амілаза, цитолітичний синдром.

повідних наказів MO3 України. Дослідження охоплювало 34 хворих на різні форми ГП. Серед них $9(26,47 \%)$ мали набрякову форму, 25 (73,53 \%) - геморагічну форму ГНП згідно з класифікацією В.С. Савельєва та співавт. (1996) [1]. Середній вік пацієнтів складав $(48,11 \pm 5,99)$ років. Чоловіки переважали - 22 (64,71 \%). Етіологія ГНП у 11 (32,35 \%) хворих - біліарного генезу, у 9 (26,47 \%) - алкогольного, у 14 (41,18 \%) - аліментарного. В осіб молодого віку переважав алкогольний фактор розвитку захворювання, в осіб середнього віку - аліментарний фактор і жовчнокам'яна хвороба, в осіб літнього віку - переважно аліментарний фактор. Лікування здійснювалося згідно зі стандартами та локальними протоколами [2]. Групу порівняння (контроль) склали 12 осіб, що підлягали плановому оперативному втручанню з приводу екстраабдомінальної патології незапального, хронічного характеру - варикозне розширення вен нижніх кінцівок - 8 (66,67 \%) осіб, пахові грижі - 4 (33,33 \%) особи.

Концентрацію $\alpha$-амілази крові визначали методом імуноферментного аналізу. Статистичний аналіз здійснювався методом варіаційної статистики з розрахунком критерію Стьюдента 3 використанням програмно-математичного комплексу комп'ютерного базування [2].

Результати дослідження та їх обговорення. Отримана нами картина динаміки амілази крові (таблиця) хворих на гострий панкреатит підтверджує думку про деструкції тканини підшлункової залози вже на ранніх етапах формування запального процесу в ній.

Як видно з таблиці, у пацієнтів контрольної групи спостерігалося вірогідне зниження активності амілази крові вже через одну добу післяопераційного періоду. Низький рівень активності амілази в цій групі утримувався до 5-ї доби і тільки на 7-му не відрізнявся від передопераційного періоду. 
ํㅗㄹ ב⿱艹

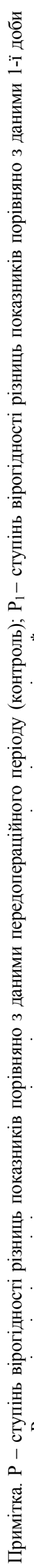

Динаміка змін активності амілази у хворих на ГП була відмінною від такої в контрольної групи. Зокрема активність амілази при набряковій формі ГП була вірогідно низькою тільки впродовж перших трьох діб спостереження, а потім спостерігалася тенденція до зростання, яка через 10 днів переходила у вірогідне зниження цього показника.

У пацієнтів із жировою формою панкреонекрозу різке пригнічення активності амілази на 1шу добу після операції змінювалось високовірогідним зростанням активності цього ферменту в подальшому. Така динаміка безумовно засвідчує розвиток вираженого цитолізу тканини підшлункової залози з виходом маркера цитолізу - амілази в кровоносне русло. Розвиток панкреонекрозу 3 тяжким перебігом супроводжувався короткочасним зниженням активності амілази, яке переходило у високовірогідну тенденцію зростання. Ця тенденція зберігалась і в подальшому, аж до кінця досліджуваного періоду. Однак значна варіабельність цього показника та відсутність прямої залежності між рівнем амілази та тяжкістю перебігу панкреатиту не дозволяють рекомендувати цей параметр як прогностичний критерій. Тим не менш, найвищі показники амілази все ж спостерігались у хворих на геморагічну та жирову форми панкреонекрозу.

\section{Висновок}

Характер змін активності амілази крові при гострому некротичному панкреатиті засвідчує розвиток цитолітичного синдрому підшлункової залози, який, тим не менш, не має чіткого вірогідного взаємозв' язку з тяжкістю перебігу захворювання.

Перспективи подальших досліджень. Дослідження доцільно розвинути у напрямку з'ясування прогностичної цінності інших показників гомеостазу для оцінки характеру та ступеня вираженості деструктивних змін при гострому панкреатиті.

\section{Література}

1. Нерешённые вопросы в лечении больных острым деструктивным панкреатитом / С.Р. Добровольский, П.М. Богопольский, В.Г. Іванов, А.Н. Сушко // Анналы хирургии. - 2004. - № 1. - С. 15-19.

2. Плегуца О.М. Деструктивний панкреатит: основи комплексного лікування / О.М. Плегуца, Р.І. Сидорчук, М.Д. Плегуца. - Чернівці: Вид-во БДМУ, 2008. $260 \mathrm{c}$.

3. Acute pancreatitis and organ failure: Pathophysiology, natural history, and management strategies / M. Raraty, S. Connor, D. Criddle [et al.] // Curr. Gastroenterol. Rep. - 2004. - № 6. - P. 99-103.

4. Dugernier T. Early multisystem organ failure associated with acute pancreatitis: A plea for a conservative therapeutic strategy / T. Dugernier, M. Reynaert, P. Laterre // Acta Gastroenterol. Belg. - 2003. - Vol. 66. - P. 177-183.

5. Kumar S.R. Acute necrotising pancreatits: Current Concepts / S.R. Kumar // Indian J. of Surgery. - 2005. - Vol. 67, № 2. - P. 78-86.

6. The Management of Acute and Chronic Pancreatitis / P.A. Banks, D.L. Conwell, P.P. Toskes [et al.] // Gastroenterol. Hepatol. - 2010. - Vol. 6 (Suppl. 5). - P. 1-16.

7. Yousaf M. Management of severe acute pancreatitis / M. Yousaf, K. McCallion, T. Diamond // Br. J. Surg. 2003. - Vol. 90. - P. 407-420. 


\section{ХАРАКТЕР АКТИВНОСТИ АЛЬФА-АМИЛАЗЫ ПЕРИФЕРИЧЕСКОЙ КРОВИ БОЛЬНЫХ С ОСТРЫМ ПАНКРЕАТИТОМ}

\section{В.К. Гродецкий}

Резюме. Острый панкреатит характеризуется значительными нарушениями различных звеньев гомеостаза. $\alpha$ амилаза является одним из важных маркеров воспаления и деструкции ткани поджелудочной железы, однако данные о динамике этого показателя являются противоречивыми. Целью исследования стало определение динамики активности $\alpha$-амилазы периферической крови в зависимости от формы острого панкреатита. Исследование включает результаты динамического обследования 34 больных различными формами острого панкреатита. Среди них 9 $(26,47$ \%) имели инфильтративную (отёчную) форму, 25 (73,53 \%) - панкреонекроз. Средний возраст пациентов составлял 48,11 $\pm 5,99$ лет. Мужчины преобладали - 22 (64,71 \%). Этиология острого панкреатита у $11(32,35 \%)$ больных - билиарного генеза, у 9 (26,47 \%) - алкогольного, у 14 (41,18 \%) - алиментарного. Установлено, что высокие показатели $\alpha$-амилазы наблюдались у больных с панкреонекрозом, однако значительная вариабельность этого показателя и отсутствие прямой зависимости между уровнем $\alpha$-амилазы и тяжестью течения панкреатита не позволяют рекомендовать этот параметр в качестве прогностического критерия. Характер изменений активности амилазы крови при остром деструктивном панкреатите свидетельствует о развитии цитолитического синдрома, который, тем не менее, не имеет чёткой возможной взаимосвязи с тяжестью течения острого панкреатита.

Ключевые слова: панкреатит, $\alpha$-амилаза, цитолитический синдром.

\section{THE NATURE OF PERIPHERAL BLOOD ALPHA-AMYLASE ACTIVITY IN PATIENTS WITH ACUTE PANCREATITIS}

\section{V.K. Hrodetskyi}

Abstract. Acute pancreatitis is characterized by significant disorders in various stages of homeostasis. $\alpha$-amylase is an important marker of inflammation and destruction of pancreatic tissue, but data on the dynamics of this variable is controversial. The aim of the study was to determine the dynamics of $\alpha$-amylase activity of peripheral blood depending on the form of acute pancreatitis. The study includes the results of dynamic examination of 34 patients with various forms of acute pancreatitis. Among them, 9 (26,47\%) had infiltrative edematous form, 25 (73,53\%) - necrotizing pancreatitis. The mean age of patients was 48,11 $\pm 5,99$ years. Male patients prevailed - $22(64,71 \%)$. The etiology of acute pancreatitis in 11 $(32,35 \%)$ patients - of biliary genesis, in $9(26,47 \%)$-alcohol, in $14(41,18 \%)$ - alimentary genesis. It is established that the highest $\alpha$-amylase activity was observed in patients with pancreatic necrosis, but high variability of this indicator and the lack of direct correlation between the level of $\alpha$-amylase and severity of pancreatitis does not allow recommending this option as a prognostic test. The nature of the changes of blood amylase activity in acute destructive pancreatitis proves development of cytolytic syndrome, which, however, has no clear relationship to severity of acute pancreatitis.

Key words: pancreatitis, $\alpha$-amylase, cytolytic syndrome.

Higher State Educational Institution of Ukraine "Bukovinian State Medical University" (Chernivtsi)

Рецензент - д. мед. н. В.В. Максим'юк Buk. Med. Herald. - 2016. - Vol. 20, № 2 (78). - P. 28-30 Надійшла до редакції 29.03.2016 року

\footnotetext{
(c) В.К. Гродецький, 2016
} 